1990

\title{
Placement and Frequency of Powerless Talk and Impression Formation
}

Craig E. Johnson

George Fox University, cjohnson@georgefox.edu

Larry Vinson

McNeese State University

Follow this and additional works at: http://digitalcommons.georgefox.edu/gfsb

Part of the Business Commons

\section{Recommended Citation}

Johnson, Craig E. and Vinson, Larry, "Placement and Frequency of Powerless Talk and Impression Formation" (1990). Faculty Publications School of Business. Paper 28.

http://digitalcommons.georgefox.edu/gfsb/28 


\title{
Placement and Frequency of Powerless Talk and Impression Formation
}

\author{
Craig Johnson and Larry Vinson
}

Study One examined the influence of initial use of hesitations and hedges on evaluations of witnesses and their persuasiveness in a budget hearing context. Results indicate that the negative attributions generated by the use of powerless language cannot be overcome by subsequent use of powerful talk. Study Two examined the relationship between the frequency of powerless language use and impression formation. For award/character and dynamism a perceptual threshold appeared to operate. The results of both studies suggest that auditors are very sensitive to the influence of powerless talk in formal settings.

KEY CONCEPTS Powerless language, hedges, negotiation, impression formation, hesitations.

CRAIG JOHNSON (Ph.D.) Associate Professor, George Fox College, 414 N. Meridian, Newberg, OR 97132-2697. LARRY R. VINSON (Ph.D.) Assistant Professor, McNeese State University, Lake Charles, LA 70609. Portions of this paper were presented at the 1987 Speech Communication Association Convention, Boston, MA. The authors would like to thank Nancy Bowen and Esther Kramer-Schlaeffer for their help in gathering data for this study. Each author contributed equally to this work.

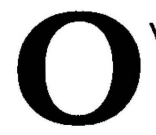

ver the past decade, a number of investigators have identified forms of language which, when used, type speakers as powerless or powerful. Powerful talk (generally operationalized as the absence of powerless language) generates high dominance and power ratings for users. Powerless speech, which includes such forms of talk as hesitation forms, hedges, tag questions and deictic phrases, characterizes sources as powerless and submissive (Bradac \& Mulac, 1984a; Johnson, 1987; Warfel, 1984). A number of studies have demonstrated that powerful speakers generate more favorable impressions than those who use powerful language forms. Sources using powerful speech have been found to be more credible (Conley, O'Barr, \& Lind, 1978; Erickson, Lind, Johnson, \& O'Barr, 1978; Lind \& O'Barr, 1979; O'Barr, 1982), more empathetic (Bradac \& Mulac, 1984b), more effective (Bradac \& Mulac, 1984a) and more persuasive (Erickson et al., 1978; Johnson \& Vinson, 1987). However, these previous investigations failed to answer a number of questions related to the effects of the location of powerless talk within a communication episode. How quickly, for example, are impressions about speakers formed on the basis of their use of powerful/powerless speech? Can a speaker who initially uses powerless talk overcome negative attributions by adopting powerful speech at a later point? Or, conversely, does a powerfully speaking source lose credibility by ending in a powerless manner?

The answers to these questions have important implications for sources since the 
frequency of powerless talk may fluctuate within communication situations. Powerless speech acts serve as markers of uncertainty and tentativeness (Ragan, 1983, p. 512; Siegman \& Pope, 1965) and these feelings may vary in intensity during a communication encounter. The amount of uncertainty is often greatest at the beginning of an interaction because participants do not know how to act in a novel situation, are not sure how the other party will respond and so on. If this is the case, the use of powerless talk may be highest during this initial period. For example, in the legal setting speakers are thrust into the unfamiliar and often threatening witness role. They may begin their testimony in a powerless manner only to overcome their initial anxiety and uncertainty and conclude in a powerful manner. However, their success as witnesses may be thwarted by their initial powerless utterances. On the other hand, witnesses may suffer significant losses in credibility and persuasiveness if they allow original straightforward talk to decay as testimony continues.

The purpose of this first study was to determine the relationship between initial use of powerful and powerless speech and evaluations of witnesses and their persuasiveness in a formal setting. Specifically, the following research questions were investigated:

Q1: What effect does beginning a message in a powerless manner and ending with powerful language have on witness credibility and persuasiveness?

Q2: What effect does beginning a message in a powerful manner and ending with powerless language have on witness credibility and persuasiveness?

Q3: Which is most damaging to witness credibility and persuasivenessbeginning with powerful talk and ending with powerless speech (PF/PL) or beginning with powerless talk and ending with powerful speech (PL/PF)?

\section{Method}

\section{Participants}

One hundred and sixty students enrolled in undergraduate communication courses at a midwestern university served as participants.

\section{Independent Variables}

\section{Context}

The stimulus materials for this project were constructed around a simulated budget allocation case used previously by Johnson and Vinson (1987).' Students were asked to act as members of the Student Senate, the student governing board on campus. They were told that one of their major responsibilities as student senators was the allocation of monies generated from student activities to student organizations applying for aid. One of the organizations seeking funding was the Negotiation Club. Participants were instructed to read a transcript of a hearing in which a representative from the Negotiation Club answered questions from the president of the Student Senate. After reading the transcript, they then determined how much the Negotiation Club should receive from the Student Senate's budget. 


\section{Powerful/Powerless Talk}

Four testimony conditions were constructed. In the powerful version of the transcript, the representative answered questions in a straightforward manner. In the powerless version of the transcript, hedges and hesitations were included at a ratio of one powerless feature for every 14 words of testimony. The powerless language forms were placed to model natural speech patterns. For example, "well" or "okay" were used as hesitation forms only at the start of a sentence. This ratio approximates that employed by Erickson et al. (1978) in their seminal research into the powerless/ powerful talk construct. Hedges ("I guess," "I think") and hesitations ("uh," "um," "ah," "well," "you know") appear to be the most frequently used forms of powerless language (Erickson et al., 1978). Both generate lower power and effectiveness ratings for users (Bradac \& Mulac, 1984a).

The two remaining testimony conditions consisted of (a) the beginning one-third of the powerful transcript followed by powerless testimony, and (b) the beginning one-third of the powerless transcript followed by the powerful testimony!

The use of written transcripts to study an oral interactive process should be addressed here. Written transcripts are useful not only because they allow the researcher to more easily collect the data but, as Bradac and Mulac (1984a, p. 310) note, they also allow for better experimental control:

In studies of lexical variation, transcribed messages eliminate "noise" which is produced by idiosyncratic aspects of voice quality, intonation, etc. and by variations in vocal presentation from one message version to another (Bradac, Konsky, \& Davies, 1976; Bradac \& Mulac, 1984a; Mulac, 1976; $\mathrm{O}^{\prime}$ Barr, 1982). In other words, the internal validity of transcribed message experiments is potentially relatively high (Bradac, 1983; Cook \& Campbell, 1979).

Not only do transcribed messages provide good control, they also generate results that mirror those produced when oral messages are employed. That is, previous studies or powerless language effects have consistently obtained nearly identical outcomes across written and oral conditions (Erickson et al., 1978; O'Barr, 1982; Vinson \& Johnson, 1989).

Because of the ease of data collection, the enhancement of experimental control, and the similarity of noted effects between oral and written messages, the majority of studies on powerless language use have used transcripts to operationalize powerless language (Bradac \& Mulac, 1984a).

\section{Dependent Variables}

Three dependent measures were employed. To measure persuasive effectiveness, subjects were asked to determine an allocation for the Negotiation Club on a range of $\$ 0$ to $\$ 5,000$. Eighteen semantic differential scales, six each representing character, competence (McCroskey \& Young, 1981) and dynamism (Berlo, Lemert, and Mertz, 1969) were used to measure witness credibility.

\section{Procedure}

Treatment conditions were represented in booklets serially containing the instructions, transcript, and award and credibility measures. Test booklets were systematically randomized and distributed to students in undergraduate courses who 
read the transcripts, determined an amount the Negotiation Club should receive and then filled out the credibility instrument.

\section{Data Analysis and Design}

The experiment was a one factor randomized design. Data were analyzed using the Reliability, MANOVA and One-way SPSSX statistical programs (Norusis, 1983). All mean contrasts were conducted using Scheffe's range tests. The statistical demarcation of .05 was set for rejecting the null hypothesis. Power was set at .80 with a moderate effect size $(.275)$ requiring a per cell $n$ of 40 (Cohen, 1977).

\section{Results}

\section{Preliminary Analysis}

Scores for each dimension of credibility were calculated and reliability checked by computing coefficient alpha (competence .89; character .60; dynamism .90). Dimensional items were then averaged and used in all subsequent analyses. Mean contrasts demonstrated that the manipulation of language power achieved the desired effects. In each case the powerful message was rated as more credible and persuasive than the powerless message (See Table 1).

\section{Multivariate Analyses}

A multivariate analysis of variance demonstrated significant effects (Wilks $=.56$; $F(16,984)=12.85 ; P<.0001$. Univariate analyses of variance were used to address the research questions.

\section{Analyses of Variance}

One-way analyses of variance found significant mean differences for award $(F(3$, $156)=4.46, P<.005$, eta $\left.{ }^{2} .08\right)$, competence $\left(\mathrm{F}(3,156)=25.8, p<.005\right.$, eta $\left.{ }^{2} .34\right)$, character $\left(F(3,156)=10.9, p<.0001\right.$, eta $\left.{ }^{2} .17\right)$ and dynamism $(F(3,156)=43.7$, $p<.00001$, eta $\left.{ }^{2} .46\right)$. Scheffe's range tests were then used to answer the research questions.

\section{Research Questions One, Two}

Questions One and Two dealt with the effect of beginning a message in either a powerless or powerful manner and ending in the opposite fashion. Mean contrasts

TABLE 1 Award, Authority, Character and Dynamism Means and Standard Deviations for Study 1

\begin{tabular}{|c|c|c|c|c|c|}
\hline & & $P F$ & $P L$ & $P F-P L$ & $P L-P F$ \\
\hline Award & $\begin{array}{c}\bar{x} \\
(\mathrm{SD})\end{array}$ & $\begin{array}{l}\text { *a } 1827 \\
(1464)\end{array}$ & $\begin{array}{c}\text { b832 } \\
(1070)\end{array}$ & $\begin{array}{c}\mathrm{b} 1229 \\
(1171)\end{array}$ & $\begin{array}{l}\mathrm{b} 1354 \\
(1120)\end{array}$ \\
\hline Competence & $\begin{array}{c}\bar{x} \\
(S D)\end{array}$ & $\begin{array}{l}{ }^{\mathrm{a}} 6.20 \\
(1.78)\end{array}$ & $\begin{array}{l}{ }^{\mathrm{b}} 2.97 \\
(1.34)\end{array}$ & $\begin{array}{l}c^{\circ} .26 \\
(1.61)\end{array}$ & $\begin{array}{l}c^{4} .25 \\
(1.79)\end{array}$ \\
\hline Character & $\begin{array}{c}\bar{x} \\
\text { (SD) }\end{array}$ & $\begin{array}{l}{ }^{\mathrm{a}} 6.27 \\
(1.14)\end{array}$ & $\begin{array}{c}b_{5.25} \\
(.68)\end{array}$ & $\begin{array}{r}\mathrm{b}_{5} .65 \\
(.64)\end{array}$ & $\begin{array}{r}5.56 \\
(.83)\end{array}$ \\
\hline Dynamism & $\begin{array}{c}\bar{x} \\
(\mathrm{SD})\end{array}$ & $\begin{array}{l}5.97 \\
(1.69)\end{array}$ & $\begin{array}{l}{ }^{b} 2.67 \\
(1.04)\end{array}$ & $\begin{array}{l}4.07 \\
(1.31)\end{array}$ & $\begin{array}{l}{ }^{3} .09 \\
(1.47)\end{array}$ \\
\hline
\end{tabular}

*Means with common superscripts do not differ significantly, $p<.05$. 
between the two combined messages (PL/PF, PF/PL) and the Powerful and Powerless conditions revealed that the use of powerless language reduced credibility ratings and award amounts regardless of where such language appeared (See Table 1). The witness who began in a powerless fashion and ended in a powerful manner or started with straightforward talk only to end with powerless language was perceived as less credible and less persuasive than the witness who used powerful speech throughout the testimony. For award and character, the PL/PF and PF/PL presentations generated ratings that were statistically equivalent to that of the Powerless Only testimony. The consistently powerless witness received lower competence ratings than did the PL/PF and PF/PL speakers. Apparently, the initially powerless source was unable to overcome the original deficit created by the use of powerless language. On the other hand, the witness who started in a powerful manner was not able to avoid negative attributions that were brought about by later use of powerless talk.

\section{Question Three}

Question Three asked which pattern was most damaging to impressions of a speaker-beginning with powerless talk and ending with powerful speech or beginning with a powerful style and ending in a powerless fashion. Mean contrasts revealed that for award, competence and character, the PL/PF and PF/PL presentations were equally damaging to the credibility and effectiveness of the witness. The presence of powerless speech apparently exerted more influence than did the location of such talk. When evaluating dynamism, however, participants gave lower ratings to the witness who began in a powerless manner. In this instance, beginning with powerless speech was more detrimental than starting with powerful language and ending in a powerless fashion (See Table 1).

\section{Discussion}

The results of Study One indicate that negative attributions generated by the use of powerless language cannot be overcome by subsequent use of powerful talk. With the exception of perceptions of competence, beginning in a powerless style was just as detrimental to the credibility and persuasiveness of the witness as using powerless talk throughout the testimony. These conclusions are disturbing because the greatest feelings of anxiety and uncertainty may occur at the beginning of a communication episode. In the public speaking setting, for example, students report the greatest feelings of apprehension at the beginning of a speech (Brownell \& Katula, 1984) and the highest use of powerless language may occur at this time. If this is the case, high initial anxiety and uncertainty is costly to speakers. Apparently, impressions of speakers are formed rapidly on the basis of their powerless language use. Once negative attributions are made, these impressions are not easily shaken. On the other hand, initial positive attributions generated by straightforward speech can be altered by the later addition of powerless language features. The witness received significantly lower credibility ratings and awards when concluding in a powerless manner. Powerless speech has a strong negative impact on perceptions of speakers and their messages, regardless of whether such talk comes at the beginning or end of a communication episode.

The results of Study One indicate that the frequency of powerless talk could play a significant role in impression formation. When judging competence, participants gave lower evaluations in the Powerless Only condition than in the PL/PF or PF/PL 
presentations. This finding suggests that higher frequencies of powerless language may be more damaging than lower frequencies. Each increase in powerless language use may lead to a corresponding linear reduction in evaluations of speakers. However, in Study One consistent powerless testimony was no more harmful to evaluations of persuasiveness, character and dynamism than beginning or ending in a powerless style. These results indicate that a perceptual threshold may be operating instead. Receivers may form a negative image of a speaker after a certain number of powerless language features have been used. Beyond this threshold, additional powerless features may not have an impact. Hosman and Wright (1987), for example, suggest that the presence of either hesitations or hedges is enough to generate negative evaluations. Once these negative attributions are made, the influence of an additional powerless language feature is minimal.

\section{Study Two}

Study Two was designed to clarify the relationship between the frequency of powerless talk and evaluations of speakers. It used the same procedure as Study One except for language frequency manipulation.

To determine if a linear or threshold model best explains the connection between powerless language use and impression formation, the budget hearing transcript used in Study One was rewritten to create four levels of powerless language use: ${ }^{2}$ (a) powerful, (b) moderate power (10 powerless features), (c) low power (19 powerless features), and (d) powerless ( 39 powerless features). Those powerless features used in the lowest concentration conditions were also used in the higher concentration conditions. For example, the low power transcript used the 10 powerless features from the moderate power condition and simply added 9 more.

In the second study, 100 students (46 males, 54 females) read the transcripts and completed the award and credibility dependent measures. Power set at .80 with a moderate effect size (.375) required a per cell $n$ of 23 (Cohen, 1977). The present study used 25 per cell.

\section{Results}

\section{Multivariate Analysis}

A multivariate analysis of variance found significant effects (Wilks $=.69, \mathrm{~F}(8$, $386)=9.5, \mathrm{P}<.0001$. Univariate tests were used to answer the research questions.

\section{Analyses of Variance}

One-way analyses of variance revealed significant mean differences between frequency conditions on each of the dependent variables: award $(F(3,96)=9.0$, $p<.0001$, eta $17.5 \%)$, competence $(F(3,96)=17.5, p<.00001$, eta $29.2 \%)$, character $\left(F(3,96)=6.4, p<.0004\right.$, eta $\left.{ }^{2} 13.1 \%\right)$, and dynamism $(F(3,96)=16$, $p<.00001$, eta $\left.{ }^{2} 27.4 \%\right)$. Scheffe's range tests were used to determine the pattern of these differences.

\section{Awards}

Participants reflected a low tolerance for powerless speech when responding to the speaker's persuasive attempt. Award amounts were significantly lower in the 
moderate power condition than in the powerful presentation (See Table 2). This result indicated that the low frequency of powerless speech features found in the moderate power presentation was enough to lower witness effectiveness. However, increasing amounts of powerless language did no further damage to the source's persuasive effort. Mean award amounts in the moderate power, low power and powerless conditions were statistically equivalent to one another (See Table 2).

\section{Competence}

Competence ratings decreased with every increase in powerless language use (See Table 2). The powerful presentation generated the highest evaluations, followed in descending order by the moderate power, low power and powerless conditions.

\section{Character}

Character ratings were less sensitive to the influence of powerless language than were evaluations of persuasiveness and competence. In this instance, only the highest frequency of powerless language generated negative attributions (See Table 2). The

TABLE 2 Award, Authority, Character and Dynamism Means and Standard Deviations for Study 2

\begin{tabular}{lcccc|c}
\hline & & Powerful & $\begin{array}{c}\text { Moderate } \\
\text { Power }\end{array}$ & $\begin{array}{c}\text { Low } \\
\text { Power }\end{array}$ & Powerless \\
\hline Award & $\overline{\mathrm{x}}$ & $\mathrm{a} 1481$ & $\mathrm{~b} 735$ & $\mathrm{~b} 414$ & $\mathrm{~b} 464$ \\
& $(\mathrm{SD})$ & $(1459)$ & $(936)$ & $(565)$ & $(404)$ \\
Competence & $\overline{\mathrm{x}}$ & $\mathrm{a} 5.20$ & $\mathrm{~b} 4.74$ & $\mathrm{c}^{3} .75$ & $\mathrm{~d}_{3.01}$ \\
& $(\mathrm{SD})$ & $(1.0)$ & $(1.74)$ & $(1.6)$ & $(.95)$ \\
Character & $\overline{\mathrm{x}}$ & $\mathrm{a} 5.50$ & 55.50 & $\mathrm{a} 5.1$ & $\mathrm{~b} 4.30$ \\
& $(\mathrm{SD})$ & $(1.09)$ & $(1.04)$ & $(1.4)$ & $(.74)$ \\
Dynamism & $\overline{\mathrm{x}}$ & $\mathrm{a} 4.48$ & $\mathrm{~b} 5.2$ & $\mathrm{c}_{3.48}$ & $\mathrm{c} 2.94$ \\
& $(\mathrm{SD})$ & $(1.59)$ & $(1.40)$ & $(1.54)$ & $(.97)$ \\
\hline
\end{tabular}

Means with common superscripts do not differ significantly, $p<.05$.

low frequencies of powerless speech employed in the moderate and low power conditions did not lower perceptions of character. Character ratings dropped significantly, however, when the maximum number of powerless features was added in the powerless presentation.

\section{Dynamism}

Dynamism ratings were highest for the moderately powerful speaker followed by the powerful speaker. The low power and powerless speakers received dynamism ratings significantly lower than the other two groups and statistically equivalent to each other (See Table 2).

\section{Discussion}

The threshold model provides a better explanation of award, character and dynamism ratings than does the linear model. The lowest number of powerless features detracted from witness persuasiveness. Once this perceptual threshold was 
crossed, additional powerful features did not lead to further reductions in award amounts. The threshold was higher when character was the outcome variable. Only the highest frequency of powerless speech lowered character ratings. For dynamism, both the low power and powerless groups generated equivalent low evaluations. However, the moderate power presentation generated higher ratings than the powerful. Only competence ratings reflected a linear relationship with powerless talk. Every increase in the level of powerless talk led to a corresponding decrease in competence ratings.

Bell, Zahn, and Hopper (1984) argue that significant findings in many powerless language studies are the result of using extremely high frequencies of powerless features, what they label as the hammer effect. The results of this investigation suggest otherwise. In the budget hearing context used in these two studies, the use of even a few powerless speech features or short durations of high frequencies of such language most often generated negative attributions. While audiences may be more tolerant of powerless language in less formal situations like conversations among friends (Bradac \& Mulac, 1984a; Warfel, 1984), acceptance ranges (Street \& Brady, 1982) may be even narrower in other formal settings like trials or public speeches. Additional research which manipulates powerless frequencies should be undertaken in other contexts to determine if this is the case. In the meantime, the findings generated by this project suggest that speakers should use powerless language with caution.

\section{NOTES}

${ }^{1,2}$ To receive copies of the transcripts used in Study One and Two contact Craig Johnson at George Fox College, 414 N. Meridian, Newberg, OR, 97132-2697.

\section{REFERENCES}

Bell, R. A., Zahn, C. J., \& Hopper, R. (1984). Disclaiming: A test of two competing views. Communication Quarterly, 32, 28-36.

Berlo, D., Lemert, J., \& Mertz, R. (1969). Dimensions for evaluating the acceptability of message sources. Public Opinion Quarterly, 33, 563-576.

Bradac, J. J. (1983). On generalizing cabbages, messages, kings, and several other things: The virtues of multiplicity. Human Communication Research, 9, 181-187.

Bradac, J. J., Hemphill, M. R., \& Tardy, C. H. (1981). Language style on trial: Effects of "powerful" and "powerless" speech upon judgments of victims and villains. Western Journal of Speech Communication, 45, 327-341.

Bradac, J. J., Konsky, C. W., \& Davies, R. A. (1976). Two studies of the effects of linguistic diversity upon judgments of communicator attributes and message effectiveness. Communication Monographs, 43, 70-79.

Bradac, J., \& Mulac, A. (1984a). A molecular view of powerful and powerless speech styles: Attributional consequences of specific language features and communicator intentions. Communication Monographs, 51, 307-319.

Bradac, J., \& Mulac, A. (1984b). Attributional consequences of powerful and powerless speech styles in a crisis intervention context. Journal of Language and Social Psychology, 3, 1-19.

Brownell, W. W., \& Katula, R. A. (1984). The Communication Anxiety Graph: A classroom tool for managing speech anxiety. Communication Quarterly, 32, 243-249.

Cohen, J. (1977). Statistical power analysis for the behavioral sciences. New York: Academic Press.

Cook, T. D., \& Cambell, D. T. (1979). Quasi-experimentation: Design and analysis issues for field settings. Chicago: Rand McNally.

Conley, J., O'Barr, W., \& Lind, E. (1978). The power of language: Presentational style in the courtroom. Duke Law Journal, 1375-1399. 
Erickson, B., Lind, E., Johnson, B., \& O'Barr, W. (1978). Speech style and impression formation in a court setting: The effects of "powerful" and "powerless" speech. Journal of Experimental Social Psychology, 14, 266-279.

Hosman, L. A., \& Wright, J. W. (1987). The effects of hedges and hesitations on impression formation in a simulated courtroom context. Western Journal of Speech Communication, $51,173-188$.

Johnson, C. (1987). An introduction to powerful and powerless talk in the classroom. Communication Education, 167-172.

Johnson, C., \& Vinson, L. (1987). "Damned if you do, damned if you don't?": Status, powerful speech and evaluations of female witnesses. Women's Studies in Communication, 10, 37-44.

Lind, E., \& O'Barr, W. (1979). The social significance of speech in the courtroom. In H. Giles \& R. St. Clair (Eds.), Language and Social Psychology (pp. 68-87). College Park, MD: University of Maryland Press.

McCroskey, J. C., \& Young, T. J. (1981). Ethos and credibility: The construct and its measurement after three decades. Central States Speech Journal, 32, 24-34!

Mulac, A. (1976). Effects of obscene language upon three dimensions of listener attitude. Communication Monographs, 43, 300-307.

Norusis, M. J. (1983). SPSSX introductory statistics guide. New York: McGraw-Hill!

O'Barr, W. (1982). Linguistic evidence: Language, power and strategy in the courtroom. New York: Academic Press.

Ragan, S. L. (1983). A conversational analysis of alignment talk in job interviews. In R. Bostrom (ed.), Communication Yearbook, 7 (pp. 502-516). Beverly Hills, CA: Sage.

Siegman, A., \& Pope, B. (1965). Effects of question specificity and anxiety-producing messages on verbal fluency in the initial interview. Journal of Personality and Social Psychology, 2, 522-530.

Street, R. L., \& Brady, R. M. (1982). Speech rate acceptance ranges as a function of evaluative domain, listener speech rate, and communication context. Communication Monographs, 49, 290-308.

Vinson, L. R., \& Johnson, C. (1989). The use of written transcripts in powerful and powerless language research. Communication Reports, 2(1), 16-21.

Warfel, K. (1984). Gender schemas and perceptions of speech style. Communication Monographs, 51, 253-267. 